\title{
CHARCOT AND BRAZIL
}

\author{
Hélio A. Ghizoni Teive', Sérgio M. Almeida², Walter Oleschko Arruda', \\ Daniel S. Sá ${ }^{3}$ Lineu C. Werneck ${ }^{4}$
}

\begin{abstract}
Objective: To describe the relationship between Professor Charcot and Brazil. Background: During the XIX century, French Neurology and its most prominent figure, Professor Charcot, dominated the area of nervous system diseases in the world. Method: We have reviewed some of the main publications about Charcot's life, the biography of Dom Pedro II, Emperor of Brazil and the development of Neurology in Brazil. Results: Among the most important patients in Charcot's practice was the Emperor of Brazil. Dom Pedro II became a close friend of Charcot and he was a distinguished guest at Charcot's house, particularly at Tuesday soirées on boulevard St. Germain. In 1887, during the visit of Dom Pedro II to France, Charcot evaluated him and made the diagnosis of surmenage. In 1889, Dom Pedro II was deposed and went to Paris, where he lived until his death in 1891. Charcot signed the death certificate and gave the diagnosis of pneumonitis. Charcot had a passionate affection for animals, a feeling shared by Dom Pedro II. Dom Pedro II was affiliated to the French Society for the Protection of Animals. It is conceivable that Charcot's little monkey, from South America, was given to him by Dom Pedro II. The Brazilian Neurological School was founded by Professor A. Austregésilo in 1911, in Rio de Janeiro. At the time, of Charcot's death in 1893, his influence was still very important in the whole world. He and his pupils played a major role in the development of Brazilian Neurology. Conclusion: Professor Charcot had a close relationship with the Emperor of Brazil, Dom Pedro II. He was his private physician and they were close friends. The neurological school, created by professor Charcot, contributed significantly, albeit in an indirect way, to the development of Brazilian Neurology, starting in 1911, in Rio de Janeiro, by Professor A. Austregésilo.
\end{abstract}

KEY WORDS: Charcot, Dom Pedro II, Brazil.

\begin{abstract}
Charcot e o Brasil
RESUMO - Objetivo: Descrever a relação entre o Professor Charcot e o Brasil. Fundamento: Durante o século $\mathrm{XIX}$, a Neurologia Francesa e a sua mais proeminente figura, o Professor Charcot, dominaram a área das doenças do sistema nervoso em todo o mundo. Método: Foram revisados algumas das principais publicações sobre a vida de Charcot, a biografia de Dom Pedro II, Imperador do Brasil, e o desenvolvimento da Neurologia no Brasil. Resultados: Entre os mais importantes pacientes de Charcot estava o Imperador do Brasil. Dom Pedro tornou-se amigo pessoal de Charcot e foi um hóspede distinto da casa de Charcot, particularmente nos jantares de terça-feira à noite, no Boulevard Saint Germain. Em 1887, durante a visita de Dom Pedro II à França, Charcot o avaliou e fez o diagnóstico de "surmenage". Em 1889, Dom Pedro II foi deposto e foi para Paris, onde viveu até a sua morte em 1891. Charcot assinou a certidão de óbito com o diagnóstico de pneumonia. Charcot teve uma afeição apaixonada por animais, um sentimento também compartilhado por Dom Pedro II, que foi afiliado da Sociedade Francesa de Proteção dos Animais. É concebível que o pequeno macaco de Charcot, oriundo da América do Sul, tenha sido um presente de Dom Pedro II. A Escola Neurológica Brasileira foi fundada pelo Professor A . Austregésilo em 1911, no Rio de Janeiro. Mesmo após a morte de Charcot em 1893, a sua influência ainda era muito importante em todo o mundo. Ele e seus pupilos tiveram um grande papel no desenvolvimento da Neurologia Brasileira. Conclusão: O Professor Charcot teve uma relação muito estreita com o Imperador do Brasil, Dom Pedro II. Ele foi o seu médico particular e amigo íntimo. A escola neurológica, criada pelo Professor Charcot, contribui significativamente, de maneira indireta, para o desenvolvimento da Neurologia Brasileira, que iniciou-se em 1911, no Rio de Janeiro, com o Professor A. Austregésilo.
\end{abstract}

PALAVRAS-CHAVE: Charcot, Dom Pedro II, Brasil.

Neurology Division and Internal Medicine Department, Hospital de Clínicas, Universidade Federal do Paraná (UFPR), Curitiba PR, Brazil: ${ }^{1}$ Assistant Professor, ${ }^{2}$ Neurologist, ${ }^{3}$ Resident, ${ }^{4}$ Head of the Neurological Service. Presented (Poster Presentations) at the $51^{\text {st }}$ annual meeting of the American Academy of Neurology, Toronto, Ontario, Canada, April 17-24, 1999.

Received 20 October 2000, received in final form 26 December 2000. Accepted 29 December 2000.

Dr. Hélio Teive - Avenida Batel 1230 / 108 - 80420-090 Curitiba PR - Brasil. FAX: 41244 5060. E-mail: hagteive@mps.com.br 


\section{J-M CHARCOT}

Jean-Martin Charcot can be recognized as the founder of Neurology as well as the first teacher of nervous system diseases in a formal way. In fact, Neurology emerged as a specialty in Internal Medicine during the second half of the XIX century, at the La Salpêtrière Hospital, in Paris, through the work of Charcot and his many disciples. Among them, we can name Bouchard (who later became his opponent in academic life), Joffroy, Debove, Raymond, Brissaud, Pierre Marie, Pitrè, Bourneville, Gilles de la Tourette, Babinski, Guinon, Souques and Meige ${ }^{1-3}$.

At this time, the French School of Neurology was known worldwide and respected as a center of reference for many physicians, who visited Charcot and his Service: Bechterew, Darkschewitch, Kojewnikow, Marinesco, Sachs and Sigmund Freud were some of them ${ }^{1-4}$.

The 'Leçons du mardi 'a la Salpêtrière", a meeting for case discussion conducted every Tuesday by Charcot, were attended by some of these famous visitors ${ }^{1-3}$. His austere and authoritarian personality were also notorious, and the German neurologists gave him the nickname Napoleonkopf (Napoleon's head) ${ }^{3}$. No doubt that through his strong character, the French School of Neurology was known all over the world and respected as a center of reference for many physicians, who visited Charcot and his Service. One of them, Professor A. Austregésilo, would become later the founder of Neurology in Brazil ${ }^{5}$.

The contribution of Charcot in describing several nervous system disorders is well known up to the present day. He studied a vast array of neurological diseases and gave classical description. To give only a few examples: the description of lateral amyotrophic sclerosis (ALS) (named after him as Charcot's disease), multiple sclerosis (Charcot and Vulpian described it as sclerose in plaques), Charcot-MarieTooth's disease (hereditary sensory and motor neuropathy), tabetic arthropathy (Charcot's joints), the clinical description of Parkinson's disease, the pathogenesis of intracerebral hemorrhage (the microaneurysms of Charcot-Bouchard). He was also interested in hysteria (hysteroepilepsia) and hypnosis - Sigmund Freud was a watchful attendee of Charcot's clinical demonstrations in this area, during his visit to the Salpêtrière ${ }^{1-4}$.

\section{DOM PEDRO II - EMPEROR OF BRAZIL}

Dom Pedro II, emperor of Brazil, "the monarch of the tropics", was an erudite and intellectual man, oftentimes bored and upsetby state matters, specially during the last years of his life, when he would pleasantly devote more and more time to intellectual work. This cultural interest increased during his travels to America and Europe. As a multilingual man, he became friendly with several famous writers and scientists of his time, e.g. Victor Hugo, Louis Pasteur, Graham Bell, Thomas Edison, and Charles Darwin among others ${ }^{6-8}$.

Dom Pedro II was a habitual visitor to the Science Academy in Paris, and he was a member of Societé d'Agriculture, Sociéte d'Hygiène, Sociéte de Zoologie, Sociéte de Geographie, Sociéte des Amis de la Science ${ }^{6,7}$. He gave a donation of 2.5 million francs towards the foundation of the Pasteur Institute. In fact, he invited Louis Pasteur several times to come to Brazil and create a research center to study yellow fever and cholera. Pasteur unfortunately declined those invitations ${ }^{6,7}$. During a session of the Academy of Sciences in Paris, Pasteur saluted the emperor of Brazil with these words:: " Notre auguste collègue Dom Pedro d'Alcantara qui aime, comme tout le monde le sait dissimuler son scéptre imperial sous des palmes académiques cueillies dans le monde entier" 8 .

In London, Dom Pedro II became a member of the Royal Academy of Sciences and an honorary member of the Institute of Anthropology ${ }^{8}$.

In 1876, Dom Pedro II made his first trip to America and took the opportunity to attend the Universal Exposition in Philadelphia. It was the first time a monarch touched the independent American territory, and he was, moreover, the only existing American monarch. His cousin, Emperor Maximilian of Mexico, was killed in 1867. This event was dedicated to commemorate the 100 years of US Independence and Republic. The event was opened by president Ulysses Grant and Dom Pedro, which give us the idea he was more known and respected as a "man of sciences and a citizen of the world" than a representation of monarchy ${ }^{6,8}$. At this time, he met Thomas Edison and Graham Bell. He was fascinated by Graham Bell's new invention, the telephone. He did not miss the chance to talk on the telephone, when, in a demonstration of his erudition, he cited Hamlet: "To be or not to be". He congratulated Mr. Bell and said Brazil would be his first client to buy his invention as soon as the telephone was marketed. In fact, a telephone was installed in Rio de Janeiro in $1880^{6-8}$.

Dom Pedro spent a good time in the US, and during his visit he became extremely popular. The "New York Herald" published a humorous note proposing Dom Pedro for president and Charles Francis Adams, vice-president, for the next American elec- 
tions, for "... we are tired of common people and we've got to change the style of the government ..." 8,9.

In Medicine, Dom Pedro II was also a well kown and good friend of French Professors Bouchard and Brown-Séquard, and Semmola and De Giovanni in Italy. But Charcot was undoubtedly his favorite friend ${ }^{6-8}$.

\section{CHARCOT AND DOM PEDRO II}

Charcot and Dom Pedro II were related in both social (as friends) and medical terms (patient-physician relationship) (Fig 1). Dom Pedro II was a distinguished guest at Charcot's Tuesday dinners at the Boulevard Saint-Germain: Charcot, avec un front trop bas, avait la rectitude d'un Bonaparte replet, recounted León Daudet ${ }^{1,3}$.As close friends, Dom Pedro enjoyed playing billiards with Charcot at his home: $D^{\prime}$ une haute stature, portant une longue barbe blanche et jouant souvent au billiard avec Charcot, according to Guillain's description '.

In 1887, during one of his trips to France, Dom Pedro underwent a medical examination by Charcot, who diagnosed him as suffering from surmenage psychico-physique (physical and psychological asthenia) (Fig 2) 1,3,6,7. Dom Pedro visited several spas and water-cure clinics in France, very popular at the end of the last century, including Aix-Les-Bains, a thermal spa in Savoy. Charcot was his companion during some of those trips ${ }^{1.3 .10}$.

Dom Pedro II was a member of the French Soci-

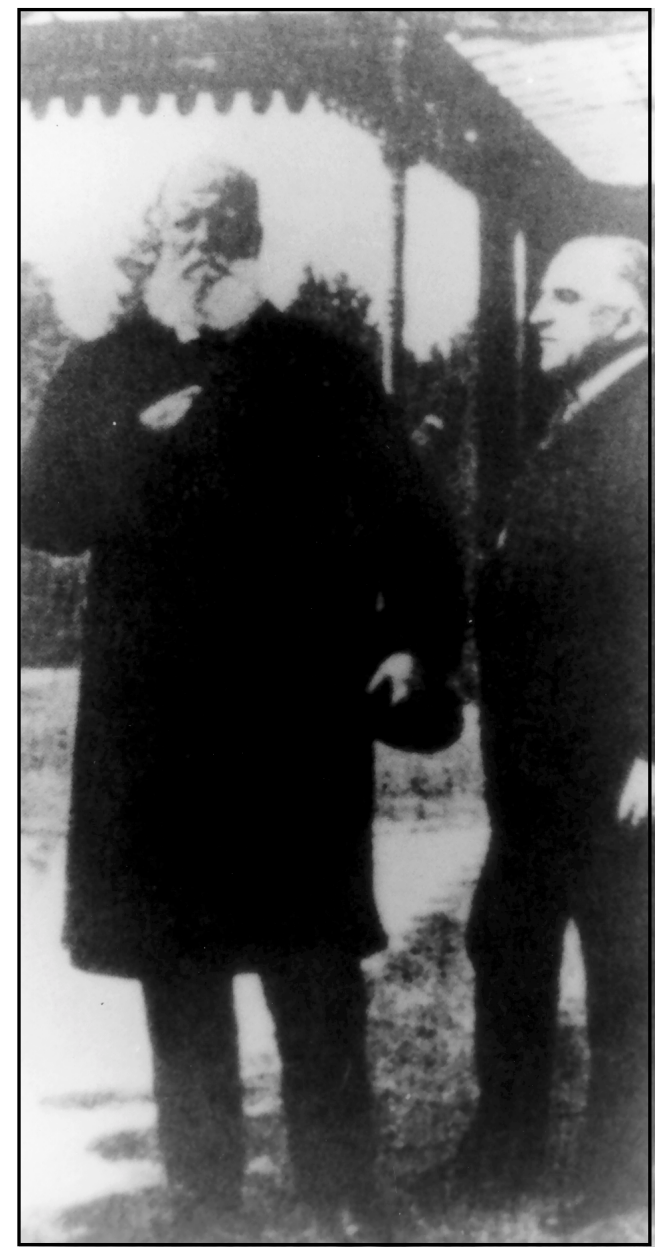

Fig 1. Charcot and Dom Pedro at the resort town of Aix-les-Bains in 1888 - Reproduced with authorization from Goetz and Bonduelle ${ }^{3}$.
Fig 2. The letter of Charcot to Dr. Motta-Maia: he comments Dom Pedro's health state and suggested therapeutics. Reproduced with authorization from Museu Imperial do Brasil.

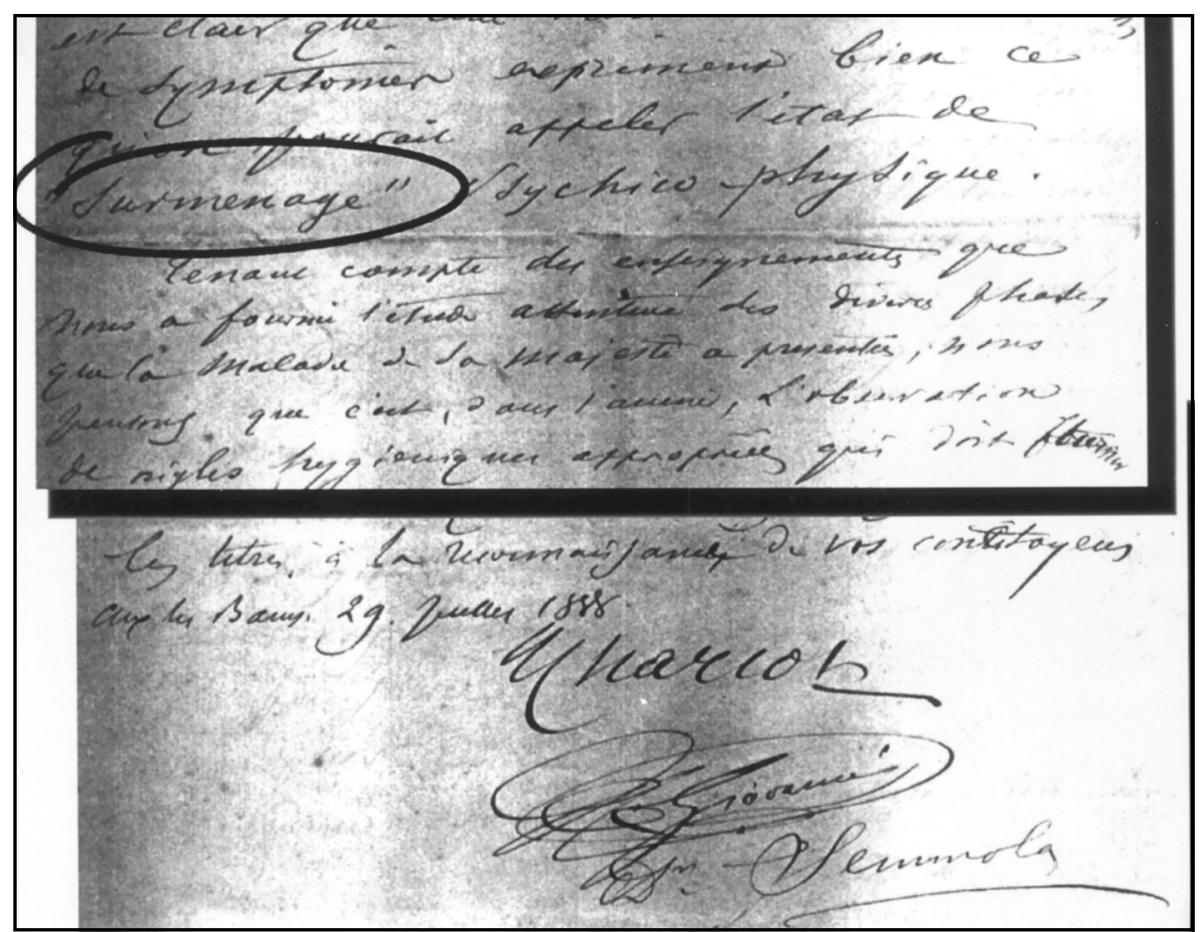






Fig 3. Charcot holding his pet monkey. Reproduced with authoriization from Goetz and Bonduelle ${ }^{3}$.

ety for the Protection of Animals. His affection to animals was deeply shared by Charcot, who never allowed vivisection of animals at the Salpetrière. Historical data suggests that the small female monkey, called Rosalie (Lees AJ, personal communication), that lived at Charcot's house and was at table during his meals, came from South America, probably a gift of Dom Pedro II to Charcot (Fig 3) 1.3.6.

In 1889, Dom Pedro was deposed by a military junta and Brazil was declared a Republic. He and his family were sent into exile in 24 hours, for the Republicans feared a popular uprise due to the great popularity Dom Pedro still enjoyed in spite of having changed "his crown for a top hat", to quote Gilberto Freyre. His wife, Teresa Cristina, died one month later, in Portugal, and he lived with his family in Paris till his death in $1891^{6-9}$.

His last years in Paris were marked by an intense cultural and social activity, though he became quite ill due to his diabetes and looked older than he actually was. His presence in Charcot's house was quite frequent ${ }^{6-8}$.

During his final illness, Dom Pedro was living at

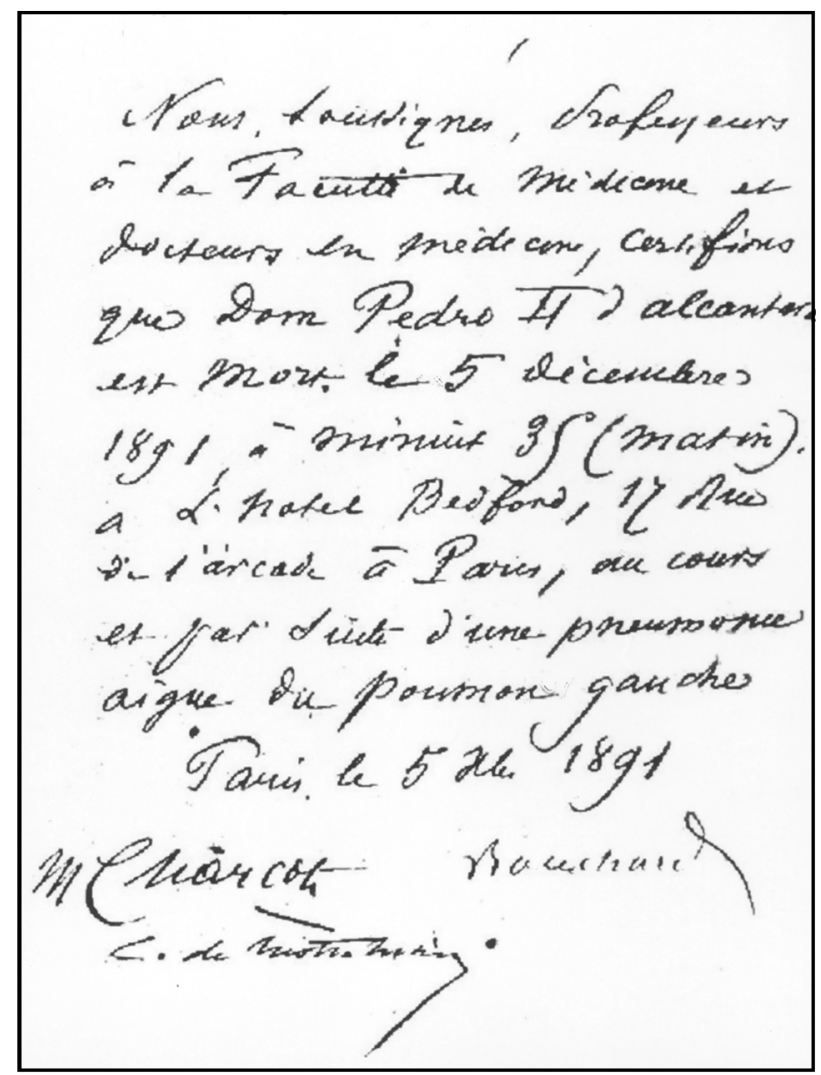

Fig 4. Dom Pedro's death certificate written by Bouchard and signed by Charcot, Dr. Motta-Maia and Bouchard himself. Reproduced from Carvalho'.

the Bedford Hotel, when Charcot diagnosed pneumonia. He finally died on December 5, 1891. Charcot with Doctors Mota Maia (Dom Pedro's personal physician) and Bouchard signed the death certificate (Fig 4) ${ }^{6-9}$.

His body was embalmed by Professor Poiret, chairman of the Faculty Service of Anatomy, Dr. Mota Maia and Charcot's son. His death caused a profound consternation in the international press, which described him as "Peter, the Good". His and his wife's bodies would return to Brazil only in 1922, the year of Brazil's centennial of independence ${ }^{6-9}$.

\section{THE CREATION OF BRAZILIAN NEUROLOGY}

In 1912, Professor Antonio Austregésilo founded the first Brazilian school of Neurology in Rio de Janeiro. Austregésilo took his MD degree with initial emphasis on Internal Medicine and Psychiatry. His interest in Neurology led him to spend a great deal of time in Europe, and particularly in France, where he visited Pierre Marie, Dejèrine and Babinski's Departments. In this sense, the French School of Neurology played a major role in the first stages of Brazilian Neurology 5,11 . 
Not surprisingly, Austregésilo career and that of his collaborators betrayed a clear influence of the French School of Neurology, more specifically Char$\cot ^{\prime}$ 's school at the Salpêtrière ${ }^{5}$. Among the several publications of A. Austregésilo, he described a variant of Babinski's sign, called Austregésilo-Esposel sign. This clinical observation was published in 1912 - Le phénomène de Babinski provoqué par l'excitation de la cuisse. ${ }^{12,13}$. Austregésilo probably gave the first description of post-traumatic dystonia in his and Marques' article Dystonies published in $1928^{14}$.

Finally, further works of Austregésilo were cited in books such as Wilson's Neurology - Sur un cas $d$ 'hemiparèsie et $d$ 'hemichorèe avec lésion du noyau caudé- and Denny-Brown's The Basal Ganglia and their relation to Disorders of Movement - Les chorèes et les manifestations choréiformes. ${ }^{15-18}$.

Acknowledgments - To Maria de Fátima Moraes Argon, archivist of Museu Imperial do Brasil, to Dr. Rubem de Andrade Arruda and Adriana Bandeira Cordeiro, Academia Nacional de Medicina, Maura Correia e Castro, Instituto Histórico e Geográfico Brasileiro, Dom Pedro Carlos Orleans e Bragança, Arquivo Grã-Pará, Dr. Ylmar Correa Neto of Universidade Federal de Santa Catarina, Dr. Francisco Germiniani and Professor Clotilde B. Germiniani of Federal University of Paraná, for providing historical documents.

Special thanks to Dr. Christopher Goetz, for authorizing the reproduction of pictures from his book Charcot: constructing neurology and Mrs. Edith Barry and Mr. Ri- chard Nash-Siedlecki of Oxford University Press, which handles all permissions.

\section{REFERENCES}

1. Guillain G. J/.-M. Charcot: his life-his work. New York: Paul B. Hoeber, 1959:-3-66.

2. Goetz CG. Charcot: the clinician. The Tuesday lessons. New York: Raven Press, 1987.

3. Goetz CG. Bonduelle M., Gelfand T. Charcot: Constructing Neurology. New York, Oxford Univ Press,1995:149-151.

4. Teive HA G. O papel de Charcot na doença de Parkinson. Arq Neuropsiquiatr 1998;56:141-145.

5. Teive HAG, Sá DS., Silveira Neto O. Silveira OA, Werneck LC. Professor Antonio Austregésilo: o pioneiro da neurologia e do estudo dos distúrbios do movimento no Brasil. Arq Neuropsiquiatr 1999;57:898-902.

6. Calmon P. História de Dom Pedro II. Rio de Janeiro: Livraria José Olímpio Editora/MEC, 1975

7. Besouchet L. Pedro II e o século XIX. Rio de Janeiro: Editora Nova Fronteira, 1993.

8. Schwarcz LM. As barbas do Imperador. D. Pedro II: um monarca nos trópicos. São Paulo: Companhia das Letras, 1998.

9. Carvalho ACV. Exílio e morte de Dom Pedro II. Revista do Instituto Histórico e Geográfico Brasileiro. Anais do Congresso de História do Segundo Reinado 1984;1:385-438.

10. Araújo CS. Dom Pedro II em Aiex-Les-Bains. Investigações. Revista do Departamento de Investigações (São Paulo) 1952;39:45-64.

11. Gomes MM. Marcos históricos da neurologia. Rio de Janeiro: Editora Científica Nacional, 1998.

12. Austregesilo A, Esposel F. Le phénomene de Babinski, provoqué par l'excitation de la cuisse. L'Encéphale 1912;7:429-436.

13. Van Gijn J. The Babinsky sign: a centenary. Utrecht: Universiteit Utrecht, 1996:.74-75.

14. Austregesilo A; Marques A. Dystonies. Rev Neurol 1928;2:562-575.

15. Austregesilo A; Galotti A . Sur un cas d'hémiparesie et d'hemichorée avec lesion du noyau caudé. Rev Neurol 1924;1:41.

16. Austregesilo A. Les chorées e les manifestations choréiformes. Rev Neurol 1931;1:179.

17. Wilson SAK. Neurology. London: Edward Arnold \& Co, 1940.

18. Denny-Brown D. The basal ganglia and their relation to disorders of movement. London: Oxford Univ Press, 1962:68. 